\title{
A Polêmica em Torno da "Ação de Direito Material"
}

\author{
Guilherme Rizzo Amaral \\ Mestre em Direito pela PUCRS \\ Doutorando em Direito Processual Civil pela UFRGS
}

\section{Introdução}

Recentes estudos ${ }^{1}$ suscitaram e, vale dizer, acirraram a polêmica em torno da ação entre nós. As formulações até hoje concebidas para a ação, seja a chamada ação de direito material, seja a ação processual, ou mesmo quando ausente tal distinção (pelo não reconhecimento da dualidade de planos - material e processual -, ou pelo não reconhecimento da dualidade de ações), não lograram êxito em pacificar a doutrina.

Pelo contrário, o que se verifica são, de um lado, vozes dentre as quais destaca-se a de Calamandrei ${ }^{2}$ - demonstrando uma

\footnotetext{
${ }^{1}$ Referimo-nos, especialmente, à polêmica sobre a ação verificada nos trabalhos de Carlos Alberto Aivaro de Oliveira ("O problema da eficácia da sentença", publicado na Revista de Processo, no 112. Out/Dez 2003, p. 9-22) e Ovídio Baptista da Silva ("Direito Material e Processo", pubilcado na Revista Magister de Direito Civil e Processual Civil no 1, Jul-Ago/2004, p. 5-29). Podemos também citar, aqui, a polêmica entre Fábio Gomes e Egas Moniz de Aragão, em torno das condições da ação e da teoria edética de Liebman, verificada em MONIZ DE ARAGÃO, Egas D. Hobbes, Montesquieu e a teoria da ação. Revista de Processo no 108, p. 09-22 e GOMES, Fábio. Comentários ao Código de Processo Civil. São Paulo: Revista dos Tribunais, 2000. vol. 3.

2 Piero Calamandrei, em seu Direito Processual Civil (Trad. Luiz Abezia e Sandra Drina Fernandez Barbery. Campinas: Bookseller, 1999. V. I, p. 203-206), embora tenha afirmado que a teoria da ação como direito facuitativo parecesse mais adequada historicamente ao processo civil italiano, deixou claro sua idéia de relativização dos conceitos de ação, ao pregar a variabilidade dos mesmos, segundo o momento histórico, e, portanto, a impossibilidade de obtenção de uma formulação válida universalmente.
} 
certa desesperança, descrédito ou submissão à confusão e à multiplicidade de idéias e formulações pretensamente universais ${ }^{3}$ em torno da ação. De outro lado, vozes de profundo dissenso e crítica muitas vezes feroz quanto às soluções apresentadas por um ou outro autor que resolveu se aventurar nos tortuosos caminhos que se encontram na "encruzilhada primordial" entre o direito material e o direito processual ${ }^{4}$. E são poucos os processualistas que não se lançaram nesta cruzada.

A polêmica em torno da ação nos agrada, particularmente, pois revela não apenas aspectos científicos relevantes para compreender o estudo do processo e sua relação com o direito material - muitas vezes esquecida e hoje ressuscitada pela valorização da instrumentalidade - como também a habilidade de nossos mestres com a palavra, seja para expressar suas idéias, seja para destruir, ou pelo menos tentar desmontar, as teses que Ihes desagradam, ainda que, por vezes, esta energia obscureça o primeiro e muito mais nobre objetivo.

Já afirmou Perelman, que "há sempre um meio de transformar uma argumentação qualquer em um silogismo, acrescentando-se uma ou várias premissas suplementares". Entretanto, continua, "o que ganhamos ao transformar num silogismo, que pode redundar numa contradição, uma argumentação não coerciva, mas que permite justificar com boas razões uma opinião plausível, a não ser a satisfação bastante pueril de demonstrar que é possivel reduzir ao mesmo esquema silogístico todos os argumentos, quaisquer que sejam?". Conclui o professor da Universidade de Bruxelas afirmando que "ao querer reduzir um argumento qualquer a um esquema formalmente válido, só se pode

${ }^{3}$ Como refere Araken de Assis, "Segundo alguns autores, a reprodução minuciosa dessas teses é inútil. Elas derivam de 'árvore genealógica frondosíssima', como observa Victor Fairén Guillén. Sobre o tema, assinalou Alessandro Pekelis, reina uma 'confusão babélica', ou seja, invencível desacerto." (ASSIS, Araken de. Cumulação de ações. SP: Revista dos Tribunais, 2002. 4a edição revista e atualizada. p. 54/55)

${ }^{4}$ A expressão "encruzilhada primordial" é cunhada por Fairén Guillén, e bem lembrada por Araken de Assis no seu livro Cumulação de ações. (SP: Revista dos Tribunais, 2002. 4a edição revista e atualizada. p. 54). 
pôr em evidência sua insuficiência. Mas, não é por não ser uma demonstração formalmente correta que uma argumentação deixa de ter valor". 5

É preciso termos presente este valioso ensinamento, não para aceitarmos teorias falhas, inconsistentes ou contraditórias acerca da ação, mas, sim, na tentativa de olharmos para cada uma das teses apresentadas com a esperança de retirar-lhes o que têm de melhor. Lê-las de forma a, ao menos querer, dar-lhes coerência. Se, ao final, não pudermos fazê-lo, poderemos mais tranqüilamente descartá-las, não descartando-lhes, nunca, o valor, que minimamente consiste na compreensão do que (pensamos) está errado para encontramos o que (pensamos) é certo ou está mais próximo disso.

Pode-se afirmar que foi a partir do reconhecimento da existência de uma relação de direito processual autônoma na obra de Oskar Bülow ${ }^{6}$ (Die Lehre von den Processeinreden und die Processvoraussetzungen, 1868), que se formularam as diversas teorias acerca da ação processual, cujo contato com o direito material (e com a sua efetiva existência como prius lógico à ação) oscilou significativamente entre as teses concreta (Adolf Wach) e abstrata (Degenkolb e Plósz e, após, Alfredo Rocco).

${ }_{5}^{5}$ PERELMAN, Chaïm. Lógica Jurídica. São Paulo: Martins Fontes, 2000. p. 3-4. 6 "Nunca se ha dudado que el derecho procesal civil determina las facuitades $y$ los deberes que ponen en mutua vinculación a las partes y al tribunal. Pero, de esa manera, se ha afirmado, también, que el proceso es una relación de derechos y obligaciones recíprocos, es decir, una relación jurídica. (...) Se acostumbra a hablar, tan sólo, de relaciones de derecho privado. A éstas, sin embargo, no puede ser referido el proceso. Desde que los derechos y las obligaciones procesales se dan entre los funcionarios del Estado y los ciudadanos, desde que se trata en el proceso de la función de los oficiales públicos y desde que, también, a las partes se las toma en cuenta únicamente en el aspecto de su vinculación y cooperación con la actividad judicial, esa relación pertenece, con toda evidencia, al derecho público y el proceso resulta, por lo tanto, una relación juridica pública. " (BÜLOW, Oskar. La Teoria de las Excepciones Procesales y los Presupuestos Procesales. Buenos Aires - EJEA, 1964, p. 1-2). 
Noticia-se, por outro lado, que o foco dos processualistas sobre o estudo desta ação de caráter processual veio acompanhado, também, de um repúdio à concepção de "ação de direito material"7. Tal decorreria da substituição - indevida, segundo Ovídio Baptista da Silva ${ }^{8}$ - da ação de direito material pela ação processual ${ }^{9}$, sob o argumento de que a vedação da auto-tutela não permitiria mais ao particular o exercício das próprias razões, submetendo-o à jurisdição estatal, provocada pela ação processual.

Neste ensaio, não nos ocuparemos da análise da ação processual e das diferentes teorias que foram formuladas acerca da mesma. É atribuído a Pekelis um levantamento de cerca de trinta e cinco formulações em torno do conceito de ação "el concepto de acción presenta en la doctrina las siguientes variedades: una simples facultad jurídica (Degenkolb), una relación jurídica (Mortara), una mera posibilidad de hecho (Bringer), un

7 Vide, neste particular, a menção à "campanha pela supressão das ações (de direito material)" que faz Ovídio Baptista da Silva, em Jurisdição e Execução na tradição romano-canônica. SP: Revista dos Tribunais, 1997. 2a edição. p. 162. a SILVA, Ovídio Baptista da Silva. Curso de Processo Civil. Porto Alegre: Fabris, 1991. $2^{a}$ ed. V. I, p. 66-67.

9 "Em última análise, como disse Alessandro Pekelis - e o repete toda a doutrina -, a ação de direito material teria sido substituída pela ação processual". (SILVA, Ovídio Baptista da. Jurisdição e Execução na tradição romano-canônica. SP: Revista dos Tribunais, 1997. $2^{a}$ edição. p. 168). En otro aspecto, se considera a la acción como un derecho frente al Estado, un derecho abstracto, un derecho a una actividad de los tribunales, un derecho cívico (Bülow, A. Rocco, Ugo Rocco, Zanzucchi), un derecho frente al Estado, una potestad de querer la actividad de los órganos estatales (Pekelis), un poder frente al ordenamiento jurídico (Ljebman), un derecho a una prestación de la persona representante de órgano jurisdiccional requerido (Carnelutti), un derecho concreto frente al Estado, un derecho a la tutela jurisdiccional (Muther, Laband, Wach, Hellwig, Stein, Schmidt, Lancheineken, Skeld), un derecho frente al obligado, un derecho concreto a una prestación procesal (Degenkolb), un derecho procesal concreto y materialmente abstracto contra el adversario procesal (Betti), un derecho potestativo, un poder frente al obligado (Chiovenda), un derecho meramente potestativo frente al Estado (Calamandrei)." (in RAMÍREZ ARCILA, Carlos. Teoría de la acción. Bogotá: Editorial Temis, 1969. p. 8-10. Trata-se de síntese atribuída a Alessandro Pekelis, constante do livro Sentencias congruentes, do processualista espanhol Pedro Aragoneses, da qual se vale Arcila para demonstrar a multiplicidade de formulações em torno do conceito de ação). 
negocio publicístico (A. Levi), una función pública (Binder), una manifestación de vida del derecho subjetivo privado (Windscheid), una arma suya de guerra (Puchta), una metamorfosis suya, que se produce como consecuencia de una violación (Savigny), una función suya (Coviello), una posición particular suya (Redenti), de un medio de tutela que acompaña al derecho subjetivo autónomo y distinto del derecho subjetivo privado (Bülow, Wach, Degenkolb, Chiovenda, Carnelutti), un poder de constituirse, mediante la proposición de la demanda, un derecho subjetivo (el derecho a la tutela jurisdiccional: así, en diverso sentido, Windscheid, Goldschmidt, Heim, Shekel), aquel derecho tal, que surge de hecho de la realizada proposición de la demanda (Bülow), una relación mediante la cual la pretensión, crisálida de un derecho subjetivo privado, se convierte en mariposa, derecho subjetivo perfecto (Mortara), un derecho posesorio, o bien una posesión del derecho correspondiente (Finci), el único derecho subjetivo realmente correspondiente al individuo respecto al cual, el llamado derecho subjetivo sustancial privado es un derecho reflejo (Pekelis). (...)

Por otra parte, es un derecho público (Wach, Degenkolb), privado, (Dünchen), un derecho público y privado, según que la voluntad de la ley cuya actuación produce, tenga naturaleza pública o privada (Chiovenda), tiene siempre un carácter publicístico, pero puede ser privada o pública según el órgano por el cual es actuada en su estímulo (Calamandrei). (...)

En otro sentido, es un derecho que corresponde solo a quien tiene efectivamente razón en el campo del derecho sustancial, y es por eso un derecho concreto (Wach, Chiovenda); el derecho de acción es concreto no ya con respecto al campo del derecho sustancial, sino con respecto a un complejo de normas intermedias entre ley sustancial y ley formal, esto es, al derecho público material judicial, Materielles Publizistiesches Ziviljustizrecht (Goldschmidt), la acción es un derecho absolutamente abstracto que prescinde de la efectiva existencia de la afirmada situación jurídica y que 


\section{6}

corresponde a quien crea de buena fe, o aun simplemente que manifieste la opinión, aun no siendo sincera, de tener un derecho (Bülow, Plosz, Degenkolb, primera edición, Mortara), la acción como derecho debe concebirse con independencia de la efectiva existencia de la afirmada situación jurídica, esto es, abstractamente, pero vista como negocio, debe entenderse, en cambio, ligada a la afirmación de la situación misma, esto es, casualmente, concretamente (Betti), se deben distinguir diversos aspectos de la acción, de modo que se pueda hablar de una coexistencia de la acción concreta y la abstracta (Calamandrei), existen en las diversas acciones que van del derecho a una simples ordenanza preliminar de rechazo, hasta el derecho a la suma obtenida de la venta, muchísimos grados de abstracción o de concreción, pero con referencia no a la existencia o no del derecho subjetivo material, sino al grado de satisfacción de la necesidad sustancial del titular (Pekelis).(...), o que denota a dificuldade que a doutrina enfrenta no trato do tema. Resolvê-lo, em breve ensaio, seria pingar mais uma gota neste mar já revolto.

Cumpre-nos, aqui, analisar o conceito de ação de direito material, e verificar, precisamente, se há sentido em falarmos em tal categoria, ou se o reconhecimento de uma ação de caráter processual obsta, no todo ou em parte, àquela concepção.

\section{A "ação de direito material"}

Costuma-se afirmar que, no direito romano, não se distinguiam ação e direito subjetivo material. Segundo refere Rogério Launia Tucci, "Os romanos, de sua vez, consideravam titulares da actio, não qualquer um, que preenchesse determinados requisitos, mas, tãosomente, aquele que demonstrasse, nas formas estabelecidas, uma situação de direito material realmente existente: só podia ser considerado titular da actio quem tivesse razão. $E$ isso porque, na verdade, o direito romano não distinguia entre actio e direito subjetivo material." 11

11 TUCCI,Rogério Lauria. Aspectos Modernos do Conceito de Ação. AJURIS 14, p. 157. 
Para a maioria dos estudiosos do direito romano, este era um sistema de ações, e não um sistema de direitos, e o conceito de ação foi cunhado, ao longo dos três periodos do procedimento romano (período das ações da lei ou legis actiones, período formulário ou per formulas, e período do procedimento extraordinário, ou cognitio extraordinem), de forma que restou cristalizado na definição de Celso, posteriormente reproduzida por Ulpiano: Nihil aliud est actio quam ius quod sibi debeatur iudicio persequendi. ${ }^{12}$

No entanto, esta ação do direito romano não se equipara à ação processual, ou seja, àquela que a doutrina de Wach, Degenkolb, Plósz e Rocco se ocuparam de definir como concreta ou abstrata. Seria frustrada qualquer tentativa de encontrar, na actio romana, uma antepassada da ação de caráter processual. Dizer que tenho ação, para o direito romano, é o mesmo que dizer "tenho direito". Neste sentido vai a lição de Vittorio Scialoja, ao qual faz coro Ovídio Baptista da Silva:

(...) cuando digo 'tengo una acción' y esta acción no la considero en su momento de actuación judicial, sino sólo como una potencialidad de llegar a esa actuación, es indubitablemente lo mismo que si dijese: 'tengo el derecho'. ${ }^{13}$

No entanto, não são poucos os equívocos que ainda se cometem ao tentar transpor o conceito de Celso para o plano processual. Como referiu Carlos Ramírez Arcila:

Em manera alguna define o corresponde a la acción procesal, a pesar de lo cual y hasta no hace mucho, era, y aún hoy continúa siendo, el derrotero de algunos de nuestros tribunales y de no pocos de nuestros profesores de derecho, para definir la

12 Tradução: "A ação não é outra coisa que o direito de perseguir em juízo o que nos é devido".

${ }^{13}$ SILVA, Ovídio Baptista da. Jurisdição e Execução na tradição romano-canônica. SP: Revista dos Tribunais, 1997. $2^{a}$ edição. p. 166. 
acción, no obstante tratarse de una concepción impropia y totalmente superada. ${ }^{14}$

Em verdade, a actio romana situava-se no plano do direito material (até porque não se reconhecia a existência do plano processual), e consistia no "poder pertencente ao titular do direito de perseguir, capturar e até matar"15. Veja-se, tratava-se de uma ação cujo exercício era privado, do particular.

Pontes de Miranda, a quem se chegou a atribuir a qualidade de "maior de nossos civilistas e maior de nossos processualistas"16, todavia, sustentou que, ainda hoje, mesmo diante da existência de ação de caráter processual (abstrata, para o jurista alagoano) e da vedação à auto-tutela, sobrevive a actio romana, denominada de "ação de direito material":

A actio romana continua de existir independente da 'ação' no sentido de invocação do juiz, 'plus' que se junta à 'actio' quando se chama o obrigado a juízo. ${ }^{17}$

Como se vê, para Pontes, coexistem duas ações: uma "ação" processual (invocação do juiz), e a actio, situada no plano do direito material.

É preciso, no entanto, situar os diferentes conceitos de direito subjetivo material, pretensão, actio e "ação". E isto o faz, precisamente, Araken de Assis, defensor das idéias de Pontes de Miranda acerca da ação de direito material.

Para Araken de Assis, o direito subjetivo é constituído da incidência de um fato na norma, encaixando-se aquele no suporte

14 RAMÍREZ ARCILA, Carlos. Teoría de la acción. Bogotá: Editorial Temis, 1969. p. 58.

${ }_{15}$ SILVA, Ovídio Baptista da. Jurisdição e Execução na tradição romano-canônica. SP: Revista dos Tribunais, 1997. $2^{a}$ edição. p. 170.

${ }^{16}$ COUTO E SILVA, Clóvis do. A teoria das ações em Pontes de Miranda. Revista da Ajuris, no 43, p. 71.

17 PONTES DE MIRANDA, Francisco Cavalcanti.

Comentários ao Código de Processo Civil. Tomo 1. RJ: Forense, 1974. P. XXIV. 
fático desta, tornando-se fato jurídico e, portanto, provocando uma nítida situação de vantagem a alguém, limitando-se a esfera de atividade de outrem. A característica primordial do direito subjetivo se revela na sua condição de estado, pois concede ao seu titular "uma posição jurídica estática e relativa". ${ }^{18}$ É, assim, "perfeitamente admissivel representar o direito subjetivo através do verbo "ter". ${ }^{19}$

Entretanto, "ter" um direito subjetivo implica, inicialmente, uma posição estática. É a exigibilidade deste mesmo direito que. Ihe outorgaria dinamicidade, nascendo, assim, a pretensão material, "o poder de exigir de outrem alguma prestação positiva ou negativa" 20 . Mais precisamente, para Pontes de Miranda, "pretensão é a posição subjetiva de poder exigir de outrem alguma prestação positiva ou negativa". ${ }^{21}$ A pretensão constitui, ainda, "figura intercalar entre o direito subjetivo e a ação". ${ }^{22}$

Chegamos, assim, à ação material, que desbordaria à fase da mera exigência, ou do mero querer, característicos da pretensão, e implicaria a atividade para a satisfação:

Nasce a ação, em benefício do titular do direito, quando o sujeito passivo não satisfaz seu dever jurídico ou, tratando-se de pretensões que se satisfazem mediante atos positivos ou negativos, ocorre uma interrupção dessa conduta. ${ }^{23}$

${ }_{18}$ ASSIS, Araken de. Cumulação de ações. SP: Revista dos Tribunais, 2002. $4^{a}$ edição revista e atualizada. p. 75.

${ }_{19}$ ASSIS, Araken de. Cumulação de ações. SP: Revista dos Tribunais, 2002. 4a edição revista e atualizada. p. 76.

${ }^{20}$ ASSIS, Araken de. Cumulação de ações. SP: Revista dos Tribunais, 2002. $4^{a}$ edição revista e atualizada. p. 76.

2: PONTES DE MIRANDA, Francisco Cavalcanti. Tratado das ações. São Paulo: Revista dos Tribunais, 1972. $2^{\text {a }}$ edição, T. I, p. 124.

${ }^{22}$ ASSIS, Araken de. Cumulação de ações. SP: Revista dos Tribunais, 2002. 4a edição revista e atualizada. p. 77.

${ }^{23}$ ASSIS, Araken de. Cumulação de ações. SP: Revista dos Tribunais, 2002. $4^{a}$ edição revista e atualizada. p. 79. 
Um passo adiante, e alcançamos a ação processual. Isto porque, em função da proibição do desforço pessoal ou da autotutela, a ação material deve ser veiculada através da "ação" processual, a que Araken de Assis equipara à demanda. ${ }^{24} \mathrm{~A}$ "ação" processual expressaria o ato de pleitear a tutela jurídica mediante sentença, acolhendo Araken de Assis a definição de RosenbergSchwab. ${ }^{25}$

Retornando a Pontes de Miranda, encontramos o exemplo para demonstrar as assertivas feitas acima:

O meu devedor constitui-se em mora e provoca a actio, que nasce a meu favor; mas ele já devia (meu direito subjetivo) e já poderia sofrer as conseqüências de ter eu contra ele pretensão. ${ }^{26}$

O exemplo não nos apresenta a ação processual e, possivelmente, não seja feliz por não situar cronologicamente o surgimento do direito subjetivo, da pretensão, da ação material (actio) e da ação processual ("ação"). Tentemos ser coerentes com a formulação de Pontes de Miranda, e apresentar um segundo e mais detalhado exemplo, partindo ainda da simples relação créditodébito:

Firmo um contrato de empréstimo, entregando determinada quantia a meu devedor, e estabelecendo um determinado prazo para pagamento. Quando da conclusão do contrato, surgiu, já, o (meu) direito subjetivo ao crédito, que me coloca em posição estática, porém, de vantagem perante o devedor. Findo o prazo para pagamento, surge a pretensão, dado que agora é exigível a quantia emprestada, ou ainda, é exigivel a conduta do devedor no sentido de solver o débito. Exercendo a pretensão, notifico meu devedor que, no entanto, não me paga a

${ }^{24}$ ASSIS, Araken de. Cumulação de ações. SP: Revista dos Tribunais, 2002. $4^{a}$ edição revista e atualizada. p. 79.

${ }^{25}$ ASSIS, Araken de. Cumulação de ações. SP: Revista dos Tribunais, 2002. $4^{a}$ edição revista e atualizada. p. 85.

26 PONTES DE MIRANDA, Francisco Cavalcanti. Comentários ao Código de Processo Civil. Tomo 1. RJ: Forense. P. XXIV. 
quantia que the emprestei, constituindo-se, portanto, em mora, e assim fazendo surgir a ação de direito material, que nasce em meu favor. Como não posso, de mãos-próprias, obter junto ao meu devedor o que me é devido (vedação à auto-tutela), me socorro da ação processual, afirmando a existência da ação de direito material perante um magistrado investido do poder jurisdicional estatal.

Fica claro, no exemplo acima utilizado, que o surgimento de uma chamada "ação de direito material" está ligado à frustração de uma pretensão devidamente exercida (ou, ainda, à resistência à tal pretensão). Pontes de Miranda suscita a possibilidade de haver ação de direito material sem pretensão (tal ocorreria com os direitos formativos: geradores, modificativos ou extintivos) ${ }^{27}$. De uma forma ou de outra, diz-se que surge a "ação de direito material" mas a esta não se atribui qualquer conseqüência jurídica relevante para a satisfação do direito ou da pretensão, a não ser a opção do autor pela "ação processual".

Isto porque, para que seja satisfeito o direito ou a pretensão resistida, será indispensável a utilização da ação processual. Neste sentido, é inequívoca a posição de Araken de Assis:

A nota característica do conceito de ação [aqui ele se refere à ação de direito material] - agir que não depende da anuência do sujeito passivo - mostra porque os ordenamentos jurídicos admitemna excepcionalmente. O exercício privado da ação provocaria tumulto social, um progressivo desfazimento dos laços da vida em sociedade, a negação da paz e do império da justiça. Por isso o Estado moderno proíbe-o, em geral, criminalizando-a como exercício arbitrário das próprias razões, e avocando, por decorrência, o monopólio da distribuição da justiça. ${ }^{28}$

27 "Pode ser que a ação seja o único elemento que se refira ao direito, e os casos, que não são raros, provam, por si sós, que a ação pode existir sem a pretensão (ou sem o resto da pretensão). Tal o que ocorre com os direitos formativos, ou sejam geradores, ou modificadores, ou extintivos, se exercíveis por ação)". PONTES DE MIRANDA, Francisco Cavalcanti. Tratado das ações. São Paulo: Revista dos Tribunais, 1972, $2^{a}$ edição, T. I, p. 115.

28 ASSIS, Araken de. Cumulação de ações. SP: Revista dos Tribunais, 2002. $4^{a}$ edição revista e atualizada. p. 79. 
Pois descobrimos, à esta altura, que a ação de direito material, exercida, ou melhor, o exercício privado da ação de direito material (e somente privado poderá sê-lo, pois a ação que se exerce na via judicial é a "ação" processual), constitui crime, salvo exceções, tais como aquela prevista no artigo $1.210, \S^{\circ}$, primeira parte, do Código Civil Brasileiro.

É claro, veja-se, que na perspectiva do direito romano, onde, segundo o romanista Salvatore Riccobbono ${ }^{29}$, o que havia era um sistema de ações, e não um sistema de direitos, e em que o agir privado, antes de ser proscrito, era a regra, a noção de actio, ou ação de direito material, ganhava relevância central.

Como bem lembra Ovídio Baptista da Silva, na magistral obra Jurisdição e Execução na tradição romano-canônica, o particular "originariamente dispunha de ação, até para 'uccidere'30 o devedor". ${ }^{31}$

Hoje, entretanto, já vimos, de qualificada pena, que o exercício privado da ação de direito material constitui crime, salvo raras exceções previstas em lei (penhor legal - art. 84 do CPC, embargo extrajudicial - art. 935, parágrafo único do $\mathrm{CPC}$, desforço imediato para defesa da posse - art. 1.210, parágrafo único do Código Civil).

Daí por que é fundamental nos indagarmos acerca da relevância do conceito de ação de direito material quando a ação processual for indispensável para a realização do direito subjetivo material do autor. Isto é: antes de negarmos por completo a existência da ação de direito material (e, parece-nos, não ser isto possivel, ante as hipóteses legais antes apresentadas), é preciso verificar se esta ação, a actio, coexiste com a ação processual.

${ }^{29}$ Apud. RAMÍREZ ARCILA, Carlos. Teoría de la acción. Bogotá: Editorial Temis, 1969. p. 55.

${ }_{30}^{30}$ Tradução: vt. matar, assassinar. Fig. Abater; destruir. (Fonte: Dicionário Michaelis).

${ }^{31}$ Jurisdição e Execução na tradição romano-canônica. SP: Revista dos Tribunais, 1997. $2^{\mathrm{a}}$ edição. p. 169. 


\section{A crítica}

Carlos Alberto Alvaro de Oliveira, em recente publicação, criticou fortemente o conceito de "ação de direito material". Afirmou o professor da Universidade Federal do Rio Grande do Sul:

Ao inserir a ação no plano do direito material, tal modo de visualizar o problema deixa obviamente de levar em conta a necessária separação entre os planos do direito material e processual.

Ora, se não é possivel afirmar a existência do direito antes do contraditório, muito menos se poderá admitir a "ação material" já no início da demanda. Sua existência só poderá ser averiguada no final do processo, com o trânsito em julgado da sentença, quando então se confundirá com a eficácia da própria sentença. (...) ao mesmo tempo em que se reconhece que o demandante não tinha ação (de direito material) afirma-se que a ação foi exercida pela "ação". Não se pode exercer o que não se tem, é o óbvio. (...) A mesma crítica pode ser endereçada ao conceito de ação de direito material, que é um agir derivado do direito material (normas dirigidas ao particular), e que mesmo assim seria exercido no processo por meio do órgão judicial, juntamente com a "ação" processual. A idéia de uma norma de conduta que contenha dentro de si o mecanismo de sua própria realização judicial, acaso violada, de modo nenhum se afina com o ordenamento jurídico brasileiro, que distingue claramente o plano do direito material e o plano do direito processual. É como admitir a existência de uma norma de primeiro grau que, ao mesmo tempo, fosse de segundo grau. (..... ${ }^{32}$

A crítica tem endereço certo: a célebre lição de Pontes de Miranda, para quem "a 'ação' exerce-se junto com a ação"333 (leia-

32 ALVARO DE OLIVEIRA, Carlos Alberto. O problema da eficácia da sentença. Revista de Processo, no 112. Out/Dez 2003.

33 PONTES DE MIRANDA, Francisco Cavalcanti. Tratado das ações. São Paulo: Revista dos Tribunais, 1972, $2^{a}$ edição, T. I, p. 94m95, 110. 
se: a ação processual - ação 'com aspas' - exerce-se junto com a ação de direito material - ação 'sem aspas'). Aliás, Pontes de Miranda vai além, ao afirmar que a ação processual é um plus que se junta à actio quando se chama o obrigado a juízo. ${ }^{34}$ Ora, sendo apenas um plus que se junta à ação de direito material, pode-se dizer que a ação processual necessita deste prius chamado de actio, ou ação de direito material, confundida no direito romano com o próprio direito subjetivo material. A tese nos traria de volta à doutrina de Wach, ou, retrocedendo ainda mais, a Savigny, assumindo que o plus seria a armadura do direito subjetivo material.

Aqui, não nos parece suficiente a ponderação de Ovídio Baptista da Silva para salvar as idéias de Pontes de Miranda:

Claro, o autor que vê rejeitada a ação (de direito material) exerceu ação (processual), sem ter direito (material), conseqüentemente sem ter actio (pretensão de direito material). Mas isso nada nos diz sobre os pressupostos que legitimaram o autor sucumbente a exercer o direito à jurisdição. ${ }^{35}$

Ora, se quisermos aceitar que alguém pode exercer ação processual sem ter ação de direito material, então não podemos admitir a idéia de Pontes de Miranda, de que uma ação exerce-se com a outra - pois nem sempre isto ocorre - e, especialmente, que a ação processual seja um plus que se junta à ação de direito material, pois nem sempre o será. Aliás, muito pelo contrário, seria mais coerente para Pontes de Miranda sustentar que a afirmação da existência de uma ação de direito material é que constitui um plus que se junta à ação processual. Age-se processualmente, exigindo a tutela jurisdicional estatal, e neste ato afirma-se (vejase: apenas afirma-se) a existência de uma ação de direito material.

34 "A actio romana continua de existir independente da 'ação' no sentido de invocação do juiz, 'plus' que se junta à 'actio' quando se chama o obrigado a juizo." PONTES DE MIRANDA, Francisco Cavalcanti. Comentários ao Código de Processo Civil. Tomo 1. RJ: Forense. P. XXIV.

${ }_{35}$ SILVA, Ovídio Baptista da. Direito Material e Processo. Revista Magister de Direito Civil e Processual Civil no 1, Jul-Ago/2004, p. 24. 
É bem verdade que Pontes de Miranda, noutras passagens, acaba sustentando algo parecido com o que propusemos acima. Assim, em seus "Comentários...".

Se, em vez de alcançar, com trânsito em julgado, sentença favorável, por ser julgada improcedente a ação (= propôs-se ação que o demandante não tinha), declara-se a inexistência da ação.

Um vez que o autor não tinha a ação, exerceu pretensão à tutela jurídica, exerceu a pretensão ao remédio jurídico processual, porque não podia esperar sentença favorável quanto à ação de que se supunha ser titular. A perda, na lide, pelo autor da ação pode consistir em se decidir que a ele não assistia pretensão à tutela jurídica, ou que, na espécie ou no caso, o remédio jurídico processual era impróprio. Aí, a sentença desfavorável não negou a existência da ação ${ }^{36}$

Aqui, resta claro que ao tratar da ação "proposta" (deixemos que o termo passe por "afirmada"), julgada improcedente, e declarada inexistente, está Pontes de Miranda tratando apenas da ação de direito material. Houve exercício da ação de direito processual, como exercício de pretensão à tutela jurídica. Caso a sentença dispusesse não haver sequer pretensão à tutela jurídica, ou caso entendesse ser equivocado o remédio processual eleito, então ter-se-ia um juízo sobre a ação processual, e não sobre a afirmação da ação de direito material (a formulação nos remete às condições da ação em Liebman, bem como aos pressupostos processuais, cuja ausência impedem o juízo de mérito).

Entretanto, a confusão volta a reinar quando se lê:

Quando se propõe uma ação, qualquer que seja, exercese a pretensão à tutela jurídica, pois o Estado, desde que se estabeleceu o monopólio estatal da justiça, a essa tutela se vinculou, e exerce-se, com o remédio jurídico processual adequado, a ação

36 PONTES DE MIRANDA, Francisco Cavalcanti. Comentários ao Código de Processo Civil. Tomo 1. RJ: Forense. P. XLIII/XLIV. 
de direito material. Às vezes se chama ação ao remédio jurídico processual (e. g., ação ordinária, ação sumária), o que leva a equívocos, devido à ambigüidade. $A$ ação é classificada conforme aquilo que se espera da sentença, se a ação for julgada procedente. Se de força eficacial preponderantemente declarativa a sentença que se espera, declarativa chama-se a ação (...). ${ }^{37}$

Ora, como afirmar que a ação de direito material seja exercida com o remédio jurídico processual adequado, se, como antes dissera Pontes de Miranda, o acerto quanto ao remédio não determina que julgar-se-á existente a ação de direito material? E, mais ainda, que ação de direito material exerce o juiz? A mesma exercida pelo particular?

Sobre o assunto, preleciona Carlos Alberto Alvaro de Oliveira:

(...) não se vê como possa o juiz agir materialmente (exercer ação de direito material, diriam Pontes de Miranda e Ovídio A. Baptista da Silva) de modo paralelo à ação processual: o que ele faz é desempenhar os atos de seu ofício, mediante o exercício dos poderes que the são conferidos por regras de direito público, totalmente distintas das regras de direito privado. Só depois de tomada a decisão (seja antecipatória, seja a própria sentença de mérito) é que o juiz pode em tese interferir no mundo sensível, agindo, mas aí já se trata do resultado da tutela jurisdicional, da própria eficácia da sentença. Antes disso, como é óbvio, não teria havido ação de direito material. Mesmo assim, esse agir do juiz não pode ser equiparado, pura e simplesmente, ao agir do particular, dada a natureza diferenciada da tutela jurisdicional e a forma substitutiva de que se reveste, destinada a reconstruir a realidade fora do processo e não apenas a reproduzi-la $(\ldots)^{38}$

37 PONTES DE MIRANDA, Francisco Cavalcanti. Comentários ao Código de Processo Civil. Tomo 1. RJ: Forense. p. XLIII

${ }^{38}$ ALVARO DE OLIVEIRA, Carlos Alberto. O problema da eficácia da sentença. Revista de Processo, no 112. Out/Dez 2003, p. 17-18. 
Realmente, não há como equiparar o agir do juiz e a actio romana, exercida pelo particular, ou a ação de direito material pregada por Pontes de Miranda. O juiz não age tal qual o particular o faria não fosse a proibição da auto-tutela. São atuações em níveis completamente distintos! Ainda assim, argumenta Ovídio Baptista da Silva:

A doutrina não leva em consideração que o monopólio estatal da jurisdição fez nascer uma segunda pretensão (exigibilidade), além daquela que o titular do direito já possuía, contra o destinatário do dever jurídico. Tanto posso exigir o pagamento (exercer pretensão) contra meu devedor, quanto posso exigir que o Estado - quando fracasse aquela exigência privada realize, por intermédio do processo, a minha pretensão. É claro que estou a tratar de ação procedente, porém não se pode obscurecer a existência das duas exigibilidades, outorgadas ao titular do direito: o agir contra o devedor (proibido, mas não eliminado) e o agir estatal, que a sentença de procedência necessariamente realiza. ${ }^{39}$

Quando Ovídio Baptista da Silva afirma que o Estado realiza, por intermédio do processo, a minha pretensão, em se tratando, é claro, de ação procedente, fica bastante claro que está o processualista a sugerir que esta pretensão é a de direito material (a mesma que embasava a ação de direito material), e não a pretensão à tutela jurisdicional. Da mesma forma, a ação procedente só pode dizer respeito à ação de direito material. Do contrário, ou seja, estivesse o notável professor a tratar da pretensão e da ação processuais, poderia dizer que por intermédio do processo se realiza a pretensão à tutela jurisdicional independentemente do resultado da sentença (procedente ou improcedente); e a ação processual, abstrata, sempre seria procedente.

${ }^{39}$ SILVA, Ovídio Baptista da. Direito Material e Processo. Revista Magister de Direito Civil e Processual Civil no 1, Jul-Ago/2004, p. 19. 
Em outras palavras, a pretensão que o Estado exerce, para Ovídio Baptista da Silva, é a pretensão de direito material, e não a pretensão à tutela jurisdicional estatal (aliás, esta é exercida pelo autor, e em face do próprio Estado!).

Portanto, para admitirmos o acerto da tese de Pontes de Miranda, defendida por Ovídio Baptista da Silva, teríamos de verificar a congruência entre a ação de direito material - proibida, mas não eliminada para Ovídio; criminalizada, para Araken de Assis - e o agir do Juiz ao prestar a tutela jurisdicional. Ainda: teríamos de afirmar que, a toda sentença procedente, deverá corresponder o exercício de uma ação de direito material, preexistente, pelo juiz!

No entanto, esta correspondência inexiste, como bem demonstra Carlos Alberto Alvaro de Oliveira:

Por outro lado, não se constata a pretendida duplicação de ações em certas demandas constitutivas, positivas ou negativas, despidas de pretensão material, a exemplo da demanda de divórcio, de anulação de casamento e de interdição. Da mesma forma, impensável a duplicação de ações no que concerne à pretensão declaratória, pois o titular do direito não pode agir por si mesmo para sua realização - com ou sem vontade do obrigado: a declaração do próprio interessado de seu próprio direito seria um flatus vocis, tornando-se indispensável a certificação que exsurge da autoridade estatal, com o exercício da jurisdição e o acolhimento da demanda. (... $)^{40}$

A lição é clara: não houvesse o monopólio da jurisdição pelo Estado, não haveria, nas relações privadas, uma ação do particular equivalente à declaração que hoje se tem pela via jurisdicional estatal.

40 ALVARO DE OLIVEIRA, Carlos Alberto. O problema da eficácia da sentença. Revista de Processo, no 112. Out/Dez 2003, p. 16. 
A observação de Carlos Alberto Alvaro de Oliveira abre a ferida de que padece a classificação das ações segundo o quanto de eficácia, assim proposta por Pontes de Miranda:

A ação é classificada conforme aquilo que se espera da sentença, se a ação for julgada procedente. Se de força eficacial preponderantemente declarativa a sentença que se espera, declarativa chama-se a ação $(. . .)^{41}$

Esta ação, é claro, só pode ser a ação de direito material, eis que a ação processual é una e abstrata (com a última assertiva concordam Carlos Alberto Alvaro de Oliveira e Ovidio Baptista da Silva ${ }^{42}$ ).

Ora, não encontramos, no plano do direito material, pretensão à declaração, constituição ou condenação (coincidentemente, as três eficácias constantes da tradicional classificação das ações sustentada por boa parte da doutrina ${ }^{43}$, arredia à teoria quinária de Pontes de Miranda). Imaginando a ausência de vedação à auto-tutela, conseguimos apenas vislumbrar a execução (de mãos próprias) e o mandamento (não no sentido de estatalidade, mas de ordens revestidas de ameaça física ou psicológica) como possíveis ações privadas.

A exemplificação, ainda que rudimentar, pode facilitar o acolhimento da assertiva anterior: Tício adquire de Caio um cavalo, e paga a este o preço. Estando Caio em mora, e ante a absoluta ausência do Estado e do binômio jurisdictio e imperium, quais seriam as ações (de direito material) imagináveis para a satisfação do direito de Tício à prestação de Caio? Poderia o primeiro buscar

\footnotetext{
41 PONTES DE MIRANDA, Francisco Cavalcanti. Tratado das ações. São Paulo: Revista dos Tribunaiș, 1972. $2^{a}$ edição, T. I, p. XLIII.

42 SILVA, Ovídio Baptista da. Direito Material e Processo. Revista Magister de Direito Civil e Processual Civil no 1, JulmAgo/2004, p. 21.

${ }_{43}$ Veja-se CINTRA, Antonio Carlos de Araújo, GRINOVER, Ada Pellegrini e DINAMARCO, Cândido Pangel. Teoria Geral do Processo, $11^{\text {a }}$ edição. São Paulo: Malheiros, 1995. p. 264/265; THEODORO JÚNIOR, Humberto. Curso de Direito Processual Civil. $41^{\text {a }}$ edição. RJ: Forense, 2004, V. 1.
} 


\section{0}

tomar à força o animal, e se no embate com o segundo saísse vencedor, veria o seu direito subjetivo material satisfeito. Poderia Tício ameaçar Caio de aplicar-lhe, ou aos seus familiares, ou mesmo a seu patrimônio, castigos físicos ou morais, e se o último cedesse a tal assédio e lhe entregasse o cavalo prometido, o primeiro, por sua ação pessoal, veria satisfeito seu direito.

Mas, perguntamo-nos se poderia Tício declarar, para todos ouvirem, que é credor de Caio, e se essa declaração de algo valeria, ou se o suposto devedor não poderia bradar já ter quitado sua obrigação e nada dever ao contrafeito credor? Ou poderia Tício, oralmente ou por escritura, constituir em caráter perene e incontestável a relação de direito material com Caio, de forma que não pudesse ser posteriormente contestada? Ainda: poderia Tício declarar não apenas ser credor de Caio como, a sua faculdade de executá-lo, atividades estas que somadas equivaleriam à condenação (aliás, já vimos que isto sequer seria necessário, ante a execução direta viável na ausência do poder jurisdicional estatal)? A resposta há de ser negativa para tais indagações!

A declaração, constituição e a condenação constituem categorias que pertencem ao plano processual, não havendo como imaginar uma ação particular capaz de outorgar a mesma certeza jurídica definitiva (e não aquela obtida pela formação de um contrato, ou de um casamento, por exemplo) que outorga a tutela jurisdicional estatal. Aliás, Ovídio Baptista da Silva já situou a condenação em plano estritamente processual, abandonando a ação condenatória como categoria do direito material. ${ }^{44}$ FaltavaIhe admitir como categorias estritamente processuais a declaração e a constituição.

Para que não sejamos mal compreendidos: a atividade praticada pelo juiz, na sentença, não se equipara àquela que poderia ser exercida pelo particular na ausência da vedação à auto-tutela. A declaração do juiz, na sentença de mérito transitada em julgado,

${ }^{44}$ SILVA, Ovídio Baptista da. A ação condenatória como categoria processual. In Da sentença liminar à nulidade da sentença. Rio de Janeiro: Forense, 2001. p. 233-251. 
dá certeza jurídica à existência ou inexistência de relação de direito material, adquirindo autoridade e o selo da imutabilidade. Nenhum particular seria capaz, por si só, de produzir idênticos efeitos (tratase da flatus vocis, já referida por Carlos Alberto Alvaro de Oliveira). Da mesma forma, ainda que eu possa firmar um contrato, ou contrair matrimônio, estas ações (privadas) poderão ser sempre submetidas à revisão pelo poder jurisdicional estatal. $E$, se este não houvesse, sendo permitida - e não criminalizada, como aduz Araken de Assis - a ação de direito material, então de nada valeria a dita constituição da relação, pois no império do arbítrio ela poderia ser renegada a qualquer tempo. O mesmo não ocorre com a constituição/desconstituição de relação jurídica por sentença transitada em julgado. Esta adquire a mesma qualidade da sentença declaratória, já referida, sendo portanto definitiva, e imune às eventuais discordâncias dos envolvidos. Quanto à condenação, sentimo-nos mais confortáveis, até, para retirá-la do plano material, pois já o fez Ovídio Batista da Silva ao afirmar que a condenação nada satisfaz, diferentemente das demais sentenças, não podendo assim constituir expressão de autêntica ação de direito material. ${ }^{45}$

Reduziríamos, assim, as ações de direito material (for the sake of argument, admitindo-as como coexistentes à ação processual, no sentido de ações privadas) a apenas duas: mandamental e executiva. Apenas estas duas ações poderia o particular exercer independentemente da participação do Estado no exercício poder jurisdicional, o que redundaria na insubsistência da classificação das ações de Pontes de Miranda, se tomadas como classificação das ações de direito material.

No entanto, remanesceria ainda outro problema. Se podemos distinguir um agir como mandamento ou execução, a mesma facilidade não encontramos para definir a pretensão material. Aquele que pretende obter um bem, que se encontra na posse de outrem, tem pretensão mandamental ou executiva?

${ }^{45}$ SILVA, Ovídio Baptista da. A ação condenatória como categoria processual. In Da sentença liminar à nulidade da sentença. Rio de Janeiro: Forense, 2001. p. 246. 
Segundo nosso Código de Processo Civil (art. 461-A), poderá o juiz ordenar que o réu entregue a coisa ou determinar a sua busca e apreensão. Poderá, portanto, mandar ou executar, independentemente do que pediu o autor em sua peça inicial (esta é a clara lição do parágrafo $5^{\circ}$ do artigo 461 do $\mathrm{CPC}$ ). Ora, dai decorre a completa impossibilidade de definirmos, a priori, se a demanda é executiva ou mandamental. Demanda-se por um bem da vida, mas o mandamento ou a execução (ou ambos, como já tivemos a oportunidade de demonstrar ${ }^{46}$ ), vêm apenas com a decisão judicial, antecipatória ou final, e não em qualquer formulação dogmática sobre uma suposta ação de direito material com carga eficacial definida.

Aqui, parece-nos claramente improcedente a crítica de Ovídio Baptista da Silva:

Entretanto, verifico que Carlos Alberto, poucas linhas antes, dera-me razão quando dissera que "a ação processual una e abstrata não pode ter conteúdo declaratório, constitutivo ou condenatório", a sugerir, agora, que essas qualidades, ou eficácias sentenciais, não estariam no direito processual, como eu afirmara com sua adesão. Porém, segundo ele, nem no direito material encontrar-se-iam as eficácias sentenciais, que ele concordara não serem também qualidades da ação processual.

Temo que exagere, mas não posso deixar de concluir que o ensaio de Carlos Alberto não foi capaz de desvendar o misterioso desaparecimento das cinco eficácias das sentenças, que não estariam nem no direito material e nem no processo. ${ }^{47}$

O temor pelo exagero justifica-se. Ocorre que, ao afirmar que as eficácias sentenciais não estão na ação processual - sendo esta abstrata - nem na ação de direito material (e, parece-nos, é precisamente o que sustenta Carlos Alberto Alvaro de Oliveira),

${ }^{45}$ AMARAL, Guilherme Rizzo. As astreintes e o processo civil brasileiro. Porto Alegre: Livraria do Advogado, 2004. P. 43 e seguintes.

47 SILVA, Ovídio Baptista da. Direito Material e Processo. Revista Magister de Direito Civil e Processual Civil no $1_{r}$ Jul-Ago/2004, p. 21. 
não se está a dizer que aquelas não estão nem no direito material, nem no processo. A não ser, é claro, que a visão de Ovídio Baptista da Silva reduza todo o plano do direito material à ação de direito material, e todo o plano processual à ação processual, admitindose assim que o direito material é igual à ação de direito material (e voltamos ao sistema de ações romano!) e que a ação processual é igual a processo.

Ora, a formulação apresentada por Carlos Alberto Alvaro de Oliveira é a de que "a eficácia se apresenta apenas como uma forma da tutela jurisdicional, outorgada a quem tenha razão, seja o autor, seja o réu (sentença declaratória negativa)" ${ }^{48}$ Está, portanto, no plano processual, mas não atrelada diretamente à ação processual, senão aos provimentos jurisdicionais.

Esta idéia é consentânea, embora não o afirme expressamente o seu autor, à de técnica de tutela, exposta por Luiz Guilherme Marinoni. Para este último, quando "se percebe, contudo, a necessidade de distinguir os meios (que permitem a prestação da tutela) do fim a ser obtido (o resultado no plano do direito material), apresenta-se como adequada a distinção entre tutela jurisdicional stricto sensu e técnicas de tutela jurisdicional". ${ }^{99}$ Assim, classifica Luiz Guilherme Marinoni as sentenças (condenatória, mandamental, etc.) como "técnicas que permitem a prestação da tutela jurisdicional", ou, simplesmente, "técnicas de tutela". ${ }^{50}$

Estas técnicas de tutela, uma vez adotadas, no plano processual, terão como objetivo buscar a produção de um resultado, este no plano material.

Daí por que é inadequado, em nosso sentir, a constante menção a ações ou mesmo demandas constitutivas, declaratórias, condenatórias, executivas ou mandamentais. A ação processual é abstrata, e a técnica de tutela empregada no processo não pode

48 ALVARO DE OLIVEIRA, Carlos Alberto. O problema da eficácia da sentença. Revista de Processo, no 112. Out/Dez 2003.

49 MARINONI, Luiz Guilherme. Tutela Específica: arts. 461, CPC e 84, CDC. São Paulo: Editora Revista dos Tribunais, 2001, p.63.

50 MARINONI, Luiz Guilherme. Tutela Especifica: arts. 461, CPC e 84, CDC. São Paulo: Editora Revista dos Tribunais, 2001, p.63. 
ser estabelecida a priori. Já a "ação de direito material" - para aqueles que a admitem -, como ação do titular independentemente da vontade do obrigado, não poderia se revestir das cargas constitutivas, declaratórias ou condenatórias, como as conhecemos; outrossim, não poderia também alinhar-se antecipadamente com a carga mandamental ou executiva, pois vimos que estas são aplicáveis sucessivamente ou até simultaneamente pelo juiz, independentemente de uma suposta ação de direito material afirmada pelo autor ${ }^{51}$.

Allás, o juiz não reconhece a existência da ação de direito material, nem mesmo nas hipóteses de sentença mandamental ou executiva (ou, diríamos, na utilização de tais técnicas de tutela). Isto porque o juiz não pode perseguir, capturar e até matar, não pode agir como o particular na ausência do Estado. O juiz está adstrito aos limites da jurisdição, dentre os quais, notadamente, destacam-se a dignidade da pessoa humana, a proibição da prisão civil, a impenhorabilidade de determinados bens, e tantos outros que não convém aqui listar, mas que demonstram claramente que a atividade jurisdicional não equipara-se à atividade privada para a satisfação dos direitos.

Em suma: a vedação à auto-tutela implica, sim, a extinção da ação de direito material, que sobrevive apenas e justamente quando aquele óbice desaparece, e é dado ao particular tutelar o seu direito, nas raras hipóteses previstas em lei.

51 "Assim, por hipótese, o juiz que determina a uma indústria que instale filtro para evitar a poluição do ar, sob pena de multa diáría, pode, sucessivamente, caso não obedecida a ordem judicial, determinar atos dos auxiliares da justiça ou de sub-rogação (eficácia executiva), tais como o fechamento da indústria ou a instalação por terceiros do referido equipamento - exemplo de aplicação sucessiva das técnicas mandamental e executiva; ou, ainda, o magistrado que determina a entrega de coisa certa sob pena de multa diária, pode, simultaneamente, determinar a busca e apreensão do bem - exemplo de aplicação simultânea das técnicas ora apontadas." (AMARAL, Guilherme Rizzo. Técnicas de tutela e o cumprimento da sentença no Projeto de Lei 3.253/04: uma análise crítica da reforma do Processo Civil brasileiro. In AMARAL, Guilherme Rizzo e CARPENA, Márcio Louzada (coordenadores). Visões Críticas do Processo Civil Brasileiro: uma homenagem ao Prof. Dr. José Maria Rosa Tesheiner. Porto Alegre: Livraria do Advogado, 2005. P. 131). 


\section{Conclusão}

Procuramos, no decorrer deste breve ensaio, demonstrar a insubsistência de duas idéias de Pontes de Miranda, quais sejam, a) o exercício de ação de direito material concomitantemente com a ação processual, e b) a classificação das ações (de direito material) segundo a sua carga de eficácia. A formulação de Pontes, defendida por Ovídio Baptista da Silva, não identifica corretamente o fenômeno de comunicação entre o direito material e o processo. Inexiste ação de direito material fora das hipóteses (raríssimas, aliás) previstas em lei. O que há, no máximo, são pretensões que, uma vez resistidas, geram o interesse na busca da tutela jurisdicional. E a busca da tutela jurisdicional estatal se dá com a ação processual, que ensejará o emprego, pelo juiz, de diferentes técnicas de tutela jurisdicional, de acordo com as necessidades e peculiaridades do direito subjetivo material tutelado e do caso concreto. 